\title{
Traitors or Traders? A Brief Analysis of Chinese Translations of Latin American Boom Writers
}

In contrast to the abundance of articles on the literary reception of magic realism in contemporary Chinese literature, textual analyses of translation seem to have been neglected. This gap in literary translation research is where my question arises: what are we reading when we read the Chinese translation of Boom writers? Most of the existing studies are centered on the translation of cultural elements ${ }^{1}$. In these discussions, comments are focused on misunderstandings, errors, omissions, imprecisions, suppressions, and the use of domestication or foreignization methods, rather than on a textual analysis of the function of translation strategies. Hence I set out to address the possible difficulties that may emerge during the translation process, and to analyze the functional dimension of the shifts in the translation based on a close reading of texts.

Although many discussions focus their attention on "errors" in literary translation, some researchers have pointed out that translation strategies should not necessarily be considered problematic. Following Lawrence Venuti's opinion in his article entitled "World Literature and Translation Studies," he frames "errors" in literary translation in this way:

\begin{abstract}
It is extremely important that the shifts in the translation not be regarded dismissively as errors in need of correction [... .] the translator has applied his own interpretants in translating the novel, a concept of equivalence [...] and a fictional discourse [...], and these choices result in a nuanced interpretation. To treat a specific verbal choice as incorrect without careful examination of the context risks the unwitting assumption of a different interpretation as a standard of evaluation. (191)
\end{abstract}

\footnotetext{
1 Research papers on this topic include the master's dissertations (some of them not published) of graduate students majoring in Translation Studies, and $\mathrm{PhD}$ theses or monographs on the reception of Latin American writers in China. These Chinese translations of the following books have been studied: El coronel no tiene quien le escriba (Chang, Hsiu-Hui 2003); Cien años de soledad (Wu, Chia-Hua 2003, Zeng, Lijun 2012); El amor en los tiempos del cólera (Zhang, Yanan 2013, Chen, Yehua 2014); Discusión (Chen, Ning 2014); La ciudad y los perros (Chang, Yi-Tzu 2012, Yan, Jia-Yi 2016); Casa verde (Hou, Jian 2017), etc.
}

Yehua Chen, Universität zu Köln

¿ Open Access. () 2020 Yehua Chen, published by De Gruyter. (c) BY-NC-ND This work is licensed under a Creative Commons Attribution-NonCommercial-NoDerivatives 4.0 International License.

https://doi.org/10.1515/9783110673678-010 
Venuti proposes not to treat deviations or transformations in translated texts as "deficiencies", "errors that denaturalize the obsessive images and the effects, or destroy the narrative techniques” (Vázquez-Ayora, "La traducción” 5, my trans.), but as a compromise or negotiation between the translators and the language system and literary conventions of the receiving context. As for the methodology, Munday suggests a reflection on two levels, namely the macro- and micro-levels. On the macro-level, the cultural context related to the predominant ideology of the society is represented through varied registers, and in the text is manifested by the narrative point of view. On the micro-level, the narrative perspective and discourse semantics are realized through the lexico-grammatical choices of the translator (47). When working with translated texts, Munday emphasizes that "the question relates to the micro-features of the style of the translator and many possible macro-factors affecting it” (47). Following these ideas, I combine these aspects in my discussion. The examples quoted and discussed in this article are taken from Chinese translations of Boom writers published from 1980 to 2014.

\section{Typography and punctuation: techniques for both authors and translators}

One of the narrative techniques deployed frequently by Mario Vargas Llosa in his works is telescopic dialogue. In Conversación en La Catedral (1969), this tool is represented in Santiago's conversation with Ambrosio, which is continued throughout the novel and is inserted into multiple dialogues that take place in various situations between different characters. In the original text, this technique works with the change of introductory verbs: when Ambrosio or Santiago speaks, the sentence begins with the present tense "dice" (says), unlike other dialogues interspersed in their conversations, which begin with the past tense "dijo" (said). Native readers can perceive this difference in direct discourse (see examples 1 and 3), as well as in free direct and free indirect discourses (examples 2 and 3). Chinese is a language without variation in verb tenses, which suggests that Chinese texts would fail to reproduce this technique. To narrate a past action in Chinese, one must employ other linguistic elements to complement the context, with auxiliary particles and prepositions. In this case, "decir" (say) works as an introductory verb in a dialogue. "Says" in the present tense can be translated to “说” (shuō), or “说道” (shuōdao), but to express "dijo" (said) in the past, it is not enough to insert an auxiliary particle, such as 说 了/说过 (shuōle/shuōguò), which is more commonly used in the perfect tense. Instead, it is essential to add an exact adverb of time (yesterday, a while ago, etc.) in order to determine the verb tense. When Sun Jiameng's translation of excerpts from 
Conversación en La Catedral was released for the first time in the literary journal World Literature (Shijiè wénxué 世界文学) in 1987, the editor He Rong (it should be noted that it may also have been the translator's own decision) pointed out the untranslatable characteristic of this literary technique ${ }^{2}$ and explained their solution to the problem, which consists in separating the two levels of dialogue through a typographical change. Thus readers can identify the core and recurrent conversation between Santiago and Ambrosio with a variant of Song style that differs from the regular one. In 1993, the People's Publishing House of Yunnan published the first complete translation of the novel by Sun in book format, in which the change in typeface was maintained. Several different publishers have since republished Sun's translation $^{3}$. Whilst reading the 2011 edition, one perceives that it is even easier to distinguish the conversations, because the font difference is more evident (from Song style to Kai style), as we can recognize in the following examples.

Example 1 -Se casó con ese muchacho que iba a la casa -dice Santiago-. Popeye Arévalo. El pecoso Arévalo.

-El flaco no se lleva bien con su viejo porque no tiene las mismas ideas -dijo Popeye. [. . .]

-El coloradito, el de las pecas - dice Ambrosio-. El hijito del senador con don Emilio Arévalo, claro. ¿Se casó con él?

-No me gustan los pecosos ni los pelirrojos- hizo una morisqueta la Teté-. Y él es las dos cosas. Uy, qué asco. (Vargas Llosa 40-43, italics added)

“蒂蒂和那个总到我们家来的小伙子结婚了。”圣地亚哥说道,“他叫波佩

耶. 阿雷瓦洛, 就是那个雀斑脸阿雷瓦洛。”

“瘦子跟他老头子的关系不太好, 两个人的想法不一样。”波佩耶说道。

“她跟女朋友到赛艇俱乐部去了。”圣地亚哥说道, “我说你怎么还不接受 教训?”

“就是红脸膛,有雀斑的那位?”安布罗修说道, “参议员堂埃米略・阿雷瓦

洛的儿子? 我当然知道。蒂蒂小姐跟他结婚了?”

“我不喜欢有雀纴的,也不喜欢红头发的。”蒂蒂做了个怪相, “而他二者兼

备。鸣呵.真叫人恶心。”

2 “本书主要的一组对话, 即圣地亚哥与安布罗修的对话, 西班牙原文作陈述式现在时以示区 别, 但译成中文, 无法表达, 故用异体字排印, 加以标明, 请读者注意” (The main conversation in the book is the one that develops between Santiago and Ambrosio. In the original Spanish text, the present tense is applied to distinguish this conversation from other conversations, however it turned out to be impossible to reproduce this technique in the Chinese translation. Therefore, we decide to use variants of the font to show the difference. We hope readers will take this into account when reading the text) (He 6).

3 These editions include Shidai Wenyi Press, 1996; People's Literature Publishing House/99 Readers, 2011 and 2017; Shanghai Art and Literature Publishing House/99 Readers, 2015. 
(Vargas Llosa, Sun translation 1993: 32-35)

“蒂蒂和那个总到我们家来的小伙子结婚了。”圣地亚哥说, “他叫波佩耶·阿雷瓦洛, 就是那 个雀斑脸阿雷瓦洛。”

“瘦子跟她老头子的关系不太好, 两个人的想法不一样。”波佩耶说道。[......

“就是红脸膛, 有雀斑的那位?”安布罗修说道, “参议员堂埃米略·阿雷瓦洛的儿子 ? 我当然 知道。蒂蒂小姐跟他结婚了?”

“我不喜欢有雀斑的, 也不喜欢红头发的。” 蒂蒂做了个怪相, “而他二者兼备。鸣呵, 真叫 人恶心。”(Vargas Llosa, Sun translation 2011: 22-25)

In the second extract, two discourses with opposite ideas appear one after the other, which creates an ironic effect. A typographical variation thus seems crucial here to reduce possible confusion during reading.

The following case is more interesting as it deals with a conversation between Santiago (S) and Ambrosio (A) including both free direct discourse (first sentence in italics) and free indirect speech (second sentence in italics). Here the S-A conversation is inserted into another one of Santiago's dialogue with Popeye in the same place. The author situates the reader in the bar La Catedral with the changing point of view of the interlocutors and separates scenes by means of two indicators: verbs in the present tense "Ambrosio señala" (Ambrosio points), and different forms of addressing Santiago, “niño” (kid) by Ambrosio or “flaco” (skinny) by Popeye.

Example 2 [.. . ] qué riquita la cholita, flaco. La pareja de la mesa vecina se levantó y Ambrosio señala a la mujer: ésa era una polilla, niño, se pasaba el día en La Catedral buscando clientes. Vieron a la pareja salir a Larco, la vieron cruzar la calle Schell. El paradero estaba ahora desierto, Expreso y colectivos pasaban semivacíos. Llamaron al mozo, dividieron la cuenta, i y por qué sabía que era polilla? Porque, además de bar-restaurante, La Catedral también era jabe, niño, detrás de la cocina había un cuartito y lo alquilaban dos soles la hora. (Vargas Llosa 48, italics added)

看。向下可以看到一个轮廊模糊的人影和一件黑色的浴衣。这乔洛姑娘太够 意思了,瘦子。圣地亚哥和波佩耶旁边桌子上的一对男女站了起来。安布罗修 指着女的说:那是个夜蝴蝶, 成天到“大教堂”来拉客。二人人看到那一对走到拉 尔柯路上,穿过雪尔大街。汽车站上这时已经没有人了, 公共汽车和私人汽车虽 过去,一半都是空的。他们唤来侍者,分推着付了账。你怎么知道那女的是娆 女? “大教堂”是个酒吧、饭馆,还兼曲会旅馆，少爷，府房后面有一间小屋子，种

金是每小时两索尔。圼地亚歌和波佩耶沿拉尔柯路一面走着,一面欣赏着从商 店里出来的姑娘和用车推着嗰呀学语的婴儿的太太。在公园门口,波佩耶买了

(Vargas Llosa, Sun translation 1993: 40)

这乔洛姑娘太够意思了, 瘦子。圣地亚哥和波佩耶旁边桌子上的一对男女站了起来。安布 罗修指着女的说: 那是个夜蝴蝶, 成天到“大教堂”来拉客。二人看到那一对走到拉尔柯路上, 
穿过雪尔大街。汽车站上这时已经没有人了。公共汽车和私人汽车驶过去, 一半都是空的。他 们唤来侍者, 分推着付了账。你怎么知道那个女的是妓女? 大教堂是个酒吧、饭馆, 还兼幽会 旅馆, 少爷, 厨房后面有一间小屋子, 租金是每小时两索尔。(Vargas Llosa, Sun translation 2011: 28)

In example 3, the author manages to merge a discourse of the free direct style into the interior monologue of Santiago. In this paragraph, the appellation "Ambrosio" at the end of the inserted discourse helps to identify the addressee of this sentence, which is not Carlitos, who appears in the principal narration. It is obvious that the translator has sufficient knowledge of Vargas Llosa's literary techniques, which concedes him a certain authority to intervene with indications that are much more explicit than those in the original text.

Example 3 Pero se había emborrachado él, piensa, como ahora tú. Carlitos se levantó, desapareció en las sombras, la risita de la mujer que moría y renacía y el piano monótono: quería emborracharte a ti y el que se ha emborrachado soy yo, Ambrosio. Ahí estaba Carlitos de nuevo: había orinado un litro de cerveza, Zavalita, qué manera de desperdiciar la plata ¿no?

- ¿Y para qué quería emborracharme? -se ríe Ambrosio-. Yo no me emborracho jamás, niño. (Vargas Llosa 437-438, italics added)

圣地亚哥回想:实际上是他先喝醉了, 然后我才醉的。卡利托斯站了起来, 消失在黑暗中,女人哧哧的荡笑断断续续, 钢琴声显得很单调。安布罗修, 我本 想把你淮醉, 可我倒先醉了。卡利托斯又回来了:我尿了一公升的唓酒,小萨,你 瞧,我们这不是在浪费钞票吗?

“您为什么想把我淮醉?”安布罗修笑了,“我从来没喝碎过,少爷。”

(Vargas Llosa, Sun translation 2011: 329)

The intervention or mediation of the translator becomes more evident and direct when they introduce their own interpretation of the original work in the text through a typographical change. At the same time, the translator runs the risk of altering the original idea of the text in the case of a misunderstanding. For instance, in the following paragraph we can observe a small but creative “mistake” of the ingenious translator when transforming Santiago's interior monologue in indirect style into an interrogative speech by Ambrosio. In the Chinese translation, each question ends with "usted", the polite form of "you" in Spanish, as if Ambrosio were asking Santiago, while in the original text it is Santiago himself evaluating his friendship during his university days. 
Example 4 Pero ya sólo se veían porque San Marcos y la política a ratos nos juntaban, piensa, ya sólo por casualidad, ya sólo por obligación. ¿ Se veían ellos solos después de la reunión de su círculo?, ¿paseaban, iban a museos o librerías o cinemas como antes con él?, ¿ lo extrañaban a él, pensaban en él, hablaban de él? (Vargas Llosa 139, italics added)

圣地亚哥回想: 我们三人还继续见面, 那只是因为圣马可和政治把我们联系在一起, 仅仅是偶 然相遇, 仅仅是出于责任感。学习小组开会后他们两人会单独会面吗? 他们还跟以前一样跟您 一起参观博物馆、逛书店、看电影 (iban a museos, librerías o cinemas con usted) 吗? 他们思 念您 (extrañaban a usted) 、想您 (pensaban en usted) 、谈论您 (hablaban de usted) 吗? (Vargas Llosa, Sun translation 2011: 99, italics added)

利维亚和危地马拉的局势。圣地亚哥回想:我们三人还继续见面,那只是因为圣 马可和政治把我们联系在一起, 仅仅是偶然相遇, 仅仅是出于责任感。学习小组 开会后他们两人单独会面吗? 他们还跟以前一样跟您一起参观博物馆、遜书店、 看电影吗? 他们思念您、想您、谈论您吗?

Even so, does this change modify the overall image of the novel or the reading experience for those who have been reading around a hundred pages of the novel and have supposedly already familiarized themselves with the narrative technique of the author? This section of text consists of a series of rhetorical questions that Santiago asks himself reflectively: "Did they take walks or movies the way they did with him before? Did they miss him, think about him, and talk about him?" With the translator's change of personal pronoun from "him" to "you", these sentences appear to be Ambrosio questioning Santiago in a persuasive way that make him reflect on his past. However, this substitution does not necessarily seem odd, or make a big difference from the reader's perspective, since the conversation between Ambrosio and Santiago is embedded in the narration as a connecter of different scenes throughout the whole structure. This intervention is probably unnecessary, but it enriches the interpretation of the novel. The translator, whether consciously or not, starts to imitate the style of the author. This translation, although not in the most expected way, shows the "the gift of mimicry" claimed by Nabokov as one of the abilities that a great literary translator should possess. For the translator, the process of translation is also a process of learning the style of the author and "impersonating his tricks of demeanor and speech, his ways and his mind, with the utmost degree of verisimilitude" (Nabokov).

Pedro Páramo (1955) is another important novel of Latin American literature both in terms of its worldwide circulation and in terms of its Chinese reception. Typographically, the author Juan Rulfo separates different narrators with the use of italics and quotation marks. In the following examples we see that he locates the remembrance of Susana in young Pedro Páramo's conversations with his 
mother and grandmother with a dash. Since the dash is often used in literary texts to indicate the beginning of a dialogue, the author encloses Pedro Páramo's analepsis in Spanish quotation marks («») in an attempt to distinguish them from the principal discourse.

Example 5 -Sí, mamá.

«Pensaba en ti, Susana. En las lomas verdes [...] Tus labios estaban mojados como si los hubiera besado besado el rocío.»

-Te he dicho que te salgas del excusado, muchacho. (Rulfo 74)

“你说得对, 妈妈。”

“我想念你, 苏珊娜。也想念那绿色的山丘。[…. 你的嘴唇十分湿润, 好像经过朝露的亲 吻。”

“我跟你说过, 快从则所里出来, 孩子。” (Rulfo, Tu translation169-170)

-Vete, pues, a limpiar el molino.

«A centenares de metros, encima de todas las nubes, más, mucho más allá de todo, estás escondida tú, Susana. Escondida en la inmensidad de Dios, detrás de su Divina Providencia, donde yo no puedo alcanzarte ni verte y adonde no llegan mis palabras. "

-Abuela, el molino no sirve, tiene el gusano roto. (Rulfo 75)

“那你就快去把磨盘打扫一下。”

“你躲藏在几百公尺的高空里, 躲藏在云端, 躲藏在很远很远的地方, 苏珊娜。你躲在上帝 那无边无际的怀抱里, 躲藏在神灵的身后。我追不上你, 也看不到你, 连我的话语也传不到你 那里。”

“奶奶, 石磨不能用了, 螺丝坏了。” (Rulfo, Tu translation 171)

According to Luraschi (22), these methods are essential in Pedro Páramo, as it is a complex text with extended dialogues, fragmented discourses and omitted introductory words for utterances. Interestingly, the Chinese translation of these fragments reveals that the absence of variation in typography eliminates the indications carefully designed by the author, which creates an unexpected effect. As a result, the text becomes more complex, since it requires the active participation of the reader to identify the romantic memories of Pedro Páramo through the changes in narrator.

In this context, it is interesting to note Sun's strategy (also probably of the editor) to change the typeface of the dialogues in Conversation in the Cathedral, which serves as an auxiliary device to help understand the structure of telescopic dialogues. The indifference of Pedro Páramo's Chinese translator to the use of punctuation nevertheless implies a choice that breaks with the Chinese narrative convention. Often regarded as extra-textual elements, typography and punctuation are easily neglected in translation. In fact, both are part of a text and have semantic and pragmatic functions. The act of modifying them can cause qualitative changes to translated texts when they are linked to the narrative structure of a literary work. In this respect, translators should scrutinize the use of typography and punctuation. 


\section{Different translators, different styles}

As we can notice from the previous examples, free direct and indirect speech, as well as changes of perspective is literary devices that Latin American Boom writers employed frequently, so that different voices and planes of characters are interspersed with each other. For example, José Donoso used a lot of these resources in El lugar sin limites (1966), in which the main narrator, La Manuela, speaks from "yo" (I). This perspective is merged with the simultaneous interventions of actions and discourses of others.

Example 6 Va apurada: tan traicioneros los vinos nuevos. Se encerró en el retrete que cabalga a la acequia del fondo del patio, junto al gallinero. Pero no, no voy a mandar a la Lucy. A la Clotilde sí. (Donoso 13)

她(Ella)忽匀忙忙地走开了 (se fue apurada), 她(ella)把自己关进(se encerró)跨在院内水沟上 的则所里, 则所旁是鸡笼。他想(él piensa)还是算了吧, 别支使露西了(él piensa que mejor no, no mandar a la Lucy), 对, 就让克劳蒂去吧。(Donoso, Duan translation 198)

露茜(Lucy)象没听见似的醉醺醺地向前走去, 新酒的后劲可真不小。她(ella)进了(entró)鸡窝 旁边的则所里, 则所盖在院犄角的下水沟上。不, 我还是不支使露茜的好 (No, mejor que yo no mando a la Lucy)。干脆让克洛蒂尔德去吧。(Donoso, Zhou and Li translation 7)

If we analyze this fragment by focusing on the subjects and introductory verbs, it is clear that the author also opts for the use of the present tense to separate the mental activities of La Manuela from the principal narration:

(La Manuela ve que Lucy) va apurada: (y piensa que son) tan traicioneros los vinos nuevos. (Lucy) Se encerró en el retrete que cabalga a la acequia del fondo del patio, junto al gallinero. (La Mauela piensa/se dice así misma) Pero no, no voy a mandar a la Lucy. A la Clotilde sí.

(La Manuela sees that Lucy) is in a hurry: (and she thinks that) new wines are so treacherous. (Lucy) locked herself in the toilet that sits astride the ditch at the back of the yard, next to the chicken coop. (La Manuela says to herself) But no, I'm not going to send Lucy. But Clotilde. (my translation)

The first quotation is from the translation by Duan Ruochuan (1986), entitled Hell without Boundaries (in Chinese没有界限的地狱méiyǒu jièxiàn dì dìyù). There are two notable changes: firstly, the speaker's first speech about wine is eliminated and instead, La Manuela's viewpoint and the omniscient perspective on Lucy's activities are united in the same sentence; secondly, a free direct discourse in the first person is replaced by a free indirect discourse in the third person. Throughout the novel we can find other similar syntactic adjustments, which verifies the consistency of this strategy (see also example 9). Without direct explanations from the translator or editors, one can suppose, based on the 
translation, that it is a strategy in order to facilitate reading. The second translation with the title Bizarre Woman (in Chinese 奇异的女人 qiyì de nürén) was released one year later. It can be understood that the two translations target the same general reading public. Despite this, the translators of this version, Zhou Yiqin and Li Hongqin, chose precision over syntactic simplification in most cases, which preserves the stylistic features of the literary work.

Gabriel García Márquez goes further in terms of narrative experiments in $\mathrm{El}$ otoño del patriarca (1975). The novel is considered the most complicated work by García Márquez. It was translated for the first time into Chinese from Russian by Yi Xin in 1985. In 2014, Xuan Le accomplished a direct translation from Spanish. The stylistic differences between the two versions have provoked a debate among Chinese readers on the quality of translation. Xuan's translation has been especially criticized for its "lack of respect for the Chinese language" 4 . The controversy motivates me to make a comparison of some fragments that possibly generated difficulties in the translation process. The particular style of syntactic organization, change of point of view, and use of punctuation in this novel constitute a great challenge when it comes to translating it into Chinese. Many obstacles to translation have their origin in the divergences between two linguistic systems. The characteristics of the Spanish language allowed the author to strongly economize the narration with the use of free direct and indirect discourse. Thus, the voices of the characters are embedded in the narrator's speech, without previous indication or introductory verbs, and without punctuation such as colons, dashes, and quotation marks.

Example 7 dicho sea sin el menor respeto mi general, pero a él no le importaba la insolencia sino la ingratitud de Patricio Aragonés a quien puse a vivir como un rey en un palacio y te di lo que nadie le ha dado a nadie en este mundo hasta prestarle mis propias mujeres, aunque mejor no hablemos de eso mi general que vale más estar capado a mazo que andar tumbando madres por el suelo como si fuera cuestión de herrar novillas. (García Márquez 32)

. 请恕我说话直爽, 我的将军! ”然而使他感到受屈辱的与其说是巴特里西奥·阿拉戈内 斯的无礼, 围宁说是他的忘恩负义: “那是你说的话吗? 你, 像国王似的住在这儿。我把自己 生平从来不给别人的东西都给了你。我甚至连自己的娘儿们也奉送给了你！”( i Acaso es algo que tú puedes decir? Tú, vives aquí como un rey. Te he dado lo que jamás he dado a los otros

4 Since the new translation of El otoño del patriarca was released, several discussions have arisen regarding this text in Douban, a virtual online community where users comment and evaluate the books they have read. For instance, one criticism of Xuan's translation is "how can they publish a translation with eight 的in only one sentence, is this even Chinese?" (的 is a structural particle that unites the owner with its property, an adjective with the noun it describes, a subordinate adjective or relative sentence with its antecedent, etc.). See https://book. douban.com/review/6700704/. 
en mi vida. ¡Hasta te regalé mis propias mujeres!) 但这时巴特里西奥·阿拉戈内斯打断了他的 话 (pero en ese momento Patricio Aragonés le interrumpió sus palabras) : “不要谈这个了, 我的将军......按倒这些不幸的妇女、这些受折磨的母亲, 就像把小母牛按倒了打烙印那样按 倒她们......” (García Márquez, Yi translation 26, emphasis added)

请恕我不敬, 将军阁下, 然而他并不在乎帕特里西奥·阿拉贡内斯的无礼却在意他的忘恩负 义, 我让你在这宫殿里过得像个国王, 我给你的没有别人能给, 世上再没有谁能像我这样甚至 连自己的女人们都借给了你, 咱们还是别谈这个了把将军阁下, 我宁愿被阉了也不想把那些做 母亲的推倒在地, 好像她们是需要被烙印的小母牛似的 (García Márquez, Xuan translation 24)

This paragraph contains four levels of discourse: "The voice of the story is that of the basic narrator. Without any indication, space or connector, the Patriarch's words are reproduced first, and then followed by that of Patricio Aragonés, as if the narrator gave them the floor or as if they were snatched from them" (Rodríguez Herrera and Valverde Acosta 45, my trans.). In Yi's translation, there is an obvious transformation from free direct and indirect speech to direct quotation. Not only does he add an indication of the change of narrator, “但这时巴特里西奥.阿拉戈内斯打断了他的话” (but at that moment Patricio Aragonés interrupted his words), an interpolation that does not exist in the source text, but he also encloses each section of speech in quotation marks. Supplementary to this syntactic simplification, the translator divides the speech into shorter sentences with a vigorous tone like “你, 像国王似的 住在这儿” (You, live here like a king) that produces a dramatic effect. This is not an individual case, but is representative of systematic shifts that are maintained throughout Yi's translation. By checking the Russian translation ${ }^{5}$, it was verified that this stylistic transformation came from the Russian. We might hypothesize that all the changes in this Chinese translation derive from the intermediary text. In this regard, Xuan's translation shows closer adherence to the Spanish source text.

In addition, El otoño del patriarca is a text that contains an abundance of Spanish recursive prepositions such as "de" (of, from, by), "por" (for, by, because, through), and "con" (with). The frequent use of these elements enables the texts to gain an "expressive economy" (Vázquez-Ayora, "Estudios estilísticos” 164-165, my trans.). Together with the scarcity of punctuation marks, a particular narrative rhythm is well established, as the following illustration of interrogative parallelism demonstrates:

5 The Russian text “Осень патриарха” is available online: lib.ru/MARKES/patriarh.txt. 
Example 8 preguntándose asustado dónde podías vivir en aquella [...], dónde estará [...] en este trueno de [...], dónde te habrás perdido en la parranda sin término del maranguango y la burundanga y el gordolobo y la manta de bandera y el tremendo salchichón de hoyito y el centavo negro de ñapa en el delirio mítico del Negro Adán y Juancito Trucupey, carajo, cuál es tu casa de vivir de este estruendo de paredes descaradas de color amarillo de ahuyama con cenefas moradas de balandrán de obispo con ventanas de verde cotorra con tabiques de azul de pelotica con pilares rosados de tu rosa en la mano, qué hora será en tu vida si estos desmerecidos [...], cuál eres tú de estas mujeres [...] mientras él preguntaba a través de [...] (García Márquez 84-85, emphasis added)

而自己却心慌意乱地想道: “你怎么能在这里居住[..... 在发臭的水洼中间好像嗅到你像兰 花般香的气息 $[\ldots . .$. 怎样能在 $[\ldots . .$. 找到你 $[\ldots .$. . 怎样找到你在这黑色亚当和 $[\ldots . .$. 怎样找到 你的房子在这贫民窟的杂乱无章的建筑里 [...... 你的钟指在几点钟 [..... 在这些女人中间怎么 样能认出你来 [......] (García Márquez, Yi translation 77)

他惊恐地问自己你能住在这片骚乱中的哪个地方，在这里，拱起的 [....... ], 你气息的甘草 味道会在这里的哪个地方, 在这里, 婊子女儿的 [......], 你会迷失在哪一处无尽的寻欢作乐 中, 在这里, 充斥着[...... 你的家是这糟乱房屋中的哪一个, 在这里, 有你的家是这糟乱房 屋中的哪一个, 在这里, 有葫芦黄的斑驳墙壁主教长袍花边般的紫色纹饰鹦武绿的窗户地球蓝 的隔断以及粉如你手中的玫瑰色立柱, 你生命的时钟究竟走到了哪一刻, 如果在这个 [......], 你究竟是这些女人中的哪一个[......] (García Márquez, Xuan translation 68-69)

In this fragment, the "unpaused accumulation of complementary expansions confers the prose a great speed" (Iglesias 40, my trans.). The phonetic iteration of nouns and adjectives rhymed with "an", "a", and "o" grants a poetic character to the text, an aspect that is regrettably but inevitably lost in the Chinese translation. If we focus on the syntactic reconstruction of this expansive narration in Chinese, the comparison of the two translations seems very interesting. Xuan resorts to syntactic amplification by adding “在这里” (here it is) after each phrase initiated with an interrogative pronoun to convey the sense of "en este trueno" (in this thunder), "de este estruendo" (of this rumble), "esto(a)s" (these). She separates the continuous discourse with more commas than in the original text, thus producing several pauses that interrupt the speech with a deceleration effect, while at the same time presenting a more obvious parallelism. Yi's translation, while supposedly a faithful reproduction of the Russian version, is deprived of punctuation marks. It only includes one colon and two quotes at the beginning to enclose the sentences and also to indicate that it is an internal monologue. Instead of starting the questions with specific interrogative pronouns, Yi extends the sentences by altering the way of asking, with structures such as “怎样 (how) ... . . 找到你 (to find you) . . . . 在这 (in this)”, “怎样 能在这 (how can in this) .... . 找到你 (to find you).” Surprisingly, Yi's translation appears to be less conventional, since it consists of an uninterrupted flow of narration that even accelerates the rhythm of the original text. 
If we only take "domestication" and "foreignization" as analytical parameters, we may be able to ascertain a general tendency in each epoch. In this case, the tension between the two strategies influences the style of the translated text, and the discrepancy in their reception reflects the changes in translation norms in both the Chinese and Russian context. For instance, the reason for making changes that favor easier and more fluid reading partly lies in Chinese translators' "anxiety over lack of readability" because they "regard readability as their highest value" (Sun “(Un) translatability” 243). Shifts motivated by translation norms are perhaps the price that literary works have to pay in order to circulate in different countries and cultures.

\section{Ideology and translation}

There are several studies that show how ideological factors can affect the results of translation. For example, the suppression of the cannibalism scene in the Chinese translation from 1985 of El otoño del patriarca: "entró el egregio general de división Rodrigo de Aguilar en bandeja de plata [. . . coliflores y laureles, macerado en especias, dorado al horno" (141), was probably the result of faithfully following the Russian translation. Zeng Lijun found that in the first Chinese translation of Cien años de soledad by Gao Changrong (1984), translated from Russian and English, the last paragraph of chapter 19 about the aunt-nephew incest was deleted (Amaranta Ursula and Aureliano) (95). After a comparison, Zeng confirmed that the Russian version that was used as a reference retained a small part of the text, and in the English version there were no changes (97), which indicates possible self-censorship by the translator concerning taboo issues of sexuality.

Ideological factors can impact not only the final product of the translation, i.e. the text itself, but also during the whole translation process, including publication. Teng Wei's research (2011) reveals a predilection in the 1950s and 1960s for translating the political and revolutionary poems of Pablo Neruda, rather than his romantic verses. The publication of Octavio Paz's Pasión crítica was put on hold for many years because one of the retired editors, hired by the publisher to review the texts, evaluated the work as "not in accordance with Marx and Lenin's view on art and literature" (98). For similar reasons, Rayuela was criticized with comments such as "an anti-communist and anti-people novel", "inferior artistic techniques" (98), and its Chinese translation took several years to appear, and was finally released in 1996. 
As I stated at the beginning of this essay, there are enough discussions in which suppression and misunderstandings in translation are given greater weight than specific translation choices. The intention of this research is to study the extent to which the translation norms, which are comprised of ideology, social-cultural taboos, the linguistic system, and the literary tradition of a country, among other factors, can affect the translated text. Therefore I am more interested in analyzing small significant shifts on the basis of a close reading. To discuss the topic of ideology and translation, we need to go back to Donoso's El lugar sin límites, which can be considered an experimental novel due to its contents (inversion of gender) and narrative methods (changeable voices), which were notable when it was published in 1966, as well as in terms of the Chinese socio-cultural context of the 1980s (when the translation was published). Both translations contain a translator's preface that reveals different attitudes towards the main character, La Manuela. In one translator's empathic description of her misfortune, she is a transvestite who "wanders in this world of hell" (Donoso, Duan translation 5, my trans.), while in the preface of the other translation, La Manuela is depicted as a "deviator with an abnormal mentality" (Li 3). From these paratextual materials we can glimpse the dominant ideology on sexuality and gender during the period when the translation was produced. However, the following example demonstrates that ideological factors, individual preferences, and stylistic considerations, are all involved in the final translation decisions.

Example $9 \mathrm{Al}$ agacharse sobre el brasero de la Clotilde para tomar el brasero de la Clotilde para tomar carbones con una lata de conservas achatada, a la Manuela le crujió el espinazo. Va a llover. Ya no estoy para estas cosas. Hasta miedo al aire de la mañana le tenía ahora, miedo a la mañana sobre todo cuando le tenía miedo a [...]

Vieja estaría pero se iba a morir cantando y con las plumas puestas. En su maleta, debajo del catre, además de su vestido de española tenía unas plumas lloronas bastante apolilladas. La Ludo se las regaló hacía años para consolarla porque un hombre no le hizo caso...cuál hombre sería, ya no me acuerdo (uno de los tantos que cuando joven me hicieron sufrir). (Donoso $14-15$, italics added)

曼努埃拉用一个扁罐头盒弯腰去克劳蒂的火盆取炭火时, 脊梁骨嘎吱嘎吱响。要下雨了。 他(él)觉得已经干不了多少事了, 现在连早晨的冷空气都怕, 特别是早晨, 有那么多东西使他 (le a él)害怕[......]

他(él)可能老了吧, 可他(él)要唱着歌、头戴着羽毛去死。在他(su masculino)床 底下的手提 箱里, 除了他的(su masculino)西班牙舞服外, 还有一些被虫蛙得很厉害的长羽毛。这些羽毛 是几年前卢多为了安慰他 (para consolarle a él) 而送的, 因为有个男人不理睬他(no le hicieron caso a él)..... 是哪个男人来着, 他(él)已经想不起来了 (年轻时那么多使他 (que le hicieron sufrir a él)受罪的男人中的一个)。(Donoso, Duan translation 199-200, emphasis added)

当她(ella)弯腰从克洛蒂的炉灶里夹出几块红炭, 装到一个已经压扁了的罐头盒里时, 她的 (su femenino)脊椎骨嘎嘎直响。看来要下雨了, 我已经干不了这 些活了。现在我(yo)真怕这早 晨的空气, 尤其是怕那随之而来的一大堆使人不 舒服的感觉 [...... ] 
我(yo)也许已经老了, 可是就是马上会死掉, 也要玩个痛快。在床下的箱子里, 除了那件西 班牙裙子, 还有一些常年搁置、被虫蛙坏了的插在帽子上的羽毛。那是几年前卢多送给我(me regaló Ludo)的, 她是为了安慰我(para consolarme), 因为一个男人抛弃了我(me abandonó)。 哪个男人呢? 现在已经记不清了, 反正是年轻时让我(me hicieron sufrir)吃了苦头的那些小伙 子中的一个。(Donoso, Zhou and Li translation 9-10, emphasis added)

There are transformations in both translations: Duan modifies the internal monologues of La Manuela and changes them into narration in the third person, and in Zhou and Li's translation of the second fragment, we can observe a shift from third person to first person. What interests us most here, rather than the significant syntactic adjustments, is the different selection of the pronouns used to refer to La Manuela: “他” (he) or “她” (she). In the light of the author's choice of word, it is evident that he treats Manuela as female, without uncertainty, using, for example, "vieja" (old) and "consolarla"(comforting her), which are both exclusive determinants regarding gender. Oddly enough, in Chinese translations produced almost in the same year, Duan chose "he", while Zhou and $\mathrm{Li}$, who include some derogatory comments regarding the blurred gender category in the preface, opted for "she." Considering other shifts that occurred in the text, we deduce that they do not belong to the category of "zero grade translation" (Vázquez-Ayora, "La traducción" 8); that is to say, these translations contain several procedures that are not elementary translation strategies. Therefore, to understand the translational decisions, which cannot be reduced to only one factor, a multi-faceted analysis must be conducted of the general context and the translator's personal preoccupations.

The reversal of gender is also notable in El beso de la mujer araña (1976), another important novel for the Chinese reception of Latin American literature. The circulation of this book in China is a very particular case that deserves more discussion not only because of its contents of homosexuality, but also for the numerous re-editions of the translation that exist in the Chinese market, with five reissues since the first release in 1988, and at least two pirated editions. The number of reprints implies that this book is in fact one of the few long-term sellers of Latin American literature in China. In 2001, the novel was even included in a collection of "World Forbidden Books." I do not doubt that it has a wide readership regardless of the limited attention from Chinese literary critics in comparison to other famous works by Boom writers.

The 2004 edition, by Yilin Press, begins with a prologue written by Chen Kaixian. A brief and general introduction about Latin American literature, some biographical information about Manuel Puig, and a synthesis of his representative works is followed by an "anticipated" summary with commentary on the novel. Chen describes homosexuality as a social problem: "Homosexuality is 
analyzed from the social, psychological and physiological aspects, a social problem that increasingly attracts our attention. The author makes a serious analysis about the formation and existence of homosexuality" (6, my trans.). He mentions the sociohistorical meaning of the book, commenting that "not only it reveals the mentality of homosexuals, but also shows an aspect of the revolutionary battle in Latin America." We can see that the nuances have not changed much, even if this is a recent publication, from 2004. The issue of homosexuality is still a sensitive topic and requires a certain level of paratextual mediation. In line with Munday's insights, "shifts on the ideological point of view [...] are more likely to entail shifts in evaluation, or higher level editing, selection and the presentation of the target text. So, evaluation is added through the paratextual commentaries, stereotyping [...]” (89). Especially when it comes to taboo issues, the preventive function of the paratext is notable, as we see in the prologues of El lugar sin limites and El beso de la mujer araña. Rather than avoiding conflict with the censorial institution, the purpose of these prologues is to prevent the public, especially the more conservative part, from being too surprised when reading the stories (Tan 64).

At the textual level, the translator Tu Mengchao also encounters with the dilemma of choosing between "he" and "she" when Molina displays his ambiguous identity:

Example $10-$ Que me dejes un poco que me escape de la realidad, ¿para qué me voy a desesperar más todavía?, ¿querés que me vuelva loco? Porque loca ya soy. (Puig 85 , italics added)

“你应该允许我逃避现实。我为什么还要使自己更加感到绝望呢? 你想我成为疯子吗? 我现 在已经是一个疯女人了啊。”(Rulfo, Tu translation 67-68, emphasis added)

-...Y a la semana siguiente fui sola al restaurant.

- ¿Sola?

-Sí, perdoname, pero cuando hablo de él yo no puedo hablar como hombre, porque no me siento hombre. (Puig 68-69, italics added)

“...... 一个星期后，小女子我就一个人去了(me, a little girl, I went alone)。”

“小女子? (Little girl?)”

“对, 请原谅。每次我讲到他时, 我不能以男人的身分说话, 因为我不觉得自己是男人。” (Rulfo, Tu translation 54, emphasis added)

In Spanish the adjectives must be matched with the form of the noun or pronoun that determines the gender and number, a grammatical rule that does not exist in the Chinese language. In the first case, the translator distinguishes "loco" from "loca", respectively "crazy" in masculine and feminine form, with “疯子” (fēngzi, crazy person, neutral) and “疯女人”(fēng nürén, crazy woman). The difficulty of translating the second dialogue into Chinese lies in the 
repetition of "sola", the feminine form of "alone" with regard to Valentín, which requires the translator to think of a one-word expression that can, ideally, convey both the sense of "alone" and Molina's female identity at the same time. Tu renders “sola” into “小女子” (xiăonứzi), which literally means "little girl", and is a modest appellation in Chinese, normally used by young girls when they refer to themselves to show humility and shyness. The use of this expression places the narrator in the Chinese context, with Molina speaking like a Chinese person, and thus delineates the figure of a delicate woman. Again, the specific translation choices show heterogeneous thinking that differs from what the prologue represents.

\section{Concluding remarks}

As this research is still ongoing, I can only provide some preliminary concluding thoughts. Existing comparative studies on the translation of Latin American works into Chinese emphasize a general trend from domestication to foreignization strategies, especially in retranslations. However, if we reduce ourselves to this conclusion, we will overlook a more diverse panorama, as exemplified in this study. Different translators with a similar background who are publishing their texts around the same time nonetheless select different translation strategies to achieve a certain narrative style. There are also discrepancies in the translation choices made regarding how to translate the same sensitive topic in the same period, revealing that some narrative novelties of the Latin American Boom fiction did not fit well into the Chinese context during the major period of their reception, or even later. Even so, shifts in translation deserve a textual analysis without addressing all the "errors" or "misunderstandings," as they may appear to be, since they imply decisions that were not taken lightly.

Our fascination with the idea of shortening the distance between two cultures, of sharing literature in different languages, of accomplishing a free circulation of literature without borders, and of undermining the Tower of Babel, which symbolizes the limited capacity of human communication, sometimes causes us to forget about the obstacles that literary works have to overcome while traveling the world. Among all these difficulties, perhaps we should employ the term "untranslatability" in a more careful way. I find it inadequate to say that a word, a text, or an author is untranslatable only from the perspective of the original text. Admittedly, there is a certain challenge to translating texts into another language, as the culture, grammar, and vocabulary of that 
language must be considered. But this does not mean that it is "untranslatable," as to translate is to choose and to compensate. As Cees Koster affirms, "it is the translator's task to make choices from the repertoire of possible means to bring about analogous effects and a corresponding narrative” (151). Behind each translation, there is a living person who works months and years, and behind each choice there is a reason. Thus, "translator, trader," proposed by Douglas Hofstadter as an alternative to the famous notion "traduttore, traditore," might be a more suitable approach, according to which we scrutinize and set forth an analysis of translations.

\section{Works cited}

Donoso, José. El lugar sin límites. Joaquín Mortiz, 1971.

--.. "Meiyou jiexian de diyu." Zhoumo yishi. Trans. Ruochuan Duan. North China Literature and Art Publishing House, 1986.

---. Qiyi de nüren. Trans. Yiqin Zhou and Hongqin Li. Culture and Art Publishing House, 1987.

García Márquez, Gabriel. El otoño del patriarca. Penguin Random House, 2014.

--.. Zuzhang de moluo. Trans. Xin Yi. Shandong Art and Literature Press, 1985.

---. Zuzhang de qiutian. Trans. Le Xuan. Nanhai Publishing Company/ Thinkingdom, 2014.

Iglesias, Julio Calviño. "El ritmo prosístico en El otoño del patriarca." Anales de literatura hispanoamericana, no. 12, 1983, pp. 29-50.

Koster, Cees. "Literary translation.” Translation: A Multidisciplinary Approach. Ed. Juliane House. Palgrave Macmillan, 2014, pp.140-157.

Luraschi, Ilse Adriana. "Narradores en la obra de Juan Rulfo: Estudio de sus funciones y efectos." Cuadernos Hispanoamericanos, no. 308, febrero, 1976, pp.5-29. www.cervan tesvirtual.com/nd/ark:/59851/bmc1z4p7, last visit 12/01/19.

Munday, Jeremy. Style and Ideology in Translation: Latin American Writing in English. Routledge, 2008.

Nabokov, Vladimir. "The art of translation.” New Republic, 04/08/1941, https://newrepublic. com/article/62610/the-art-translation, last visit 19/01/19.

Puig, Manuel. El beso de la mujer araña. Seix Barral, 2001.

-. Zhizhunü zhiwen. Trans. Mengchao Tu. Yilin Press, 2008.

Rodríguez Herrera, María Elia, and Carmen María Valverde Acosta. "Los estilos indirecto y directo libres: Un aporte a su definición.” Revista de Filología y Lingüística de la Universidad de Costa Rica, no. 1-2, 1981, pp. 43-48.

Rulfo, Juan. Hu'an lu'erfu zhongduanpian xiaoshuoji. Trans. Mengchao Tu. Foreign Literature Press, 1980.

---. Pedro Páramo. Cátedra, 2010.

Sun, Yifeng. "(Un)translatability and cross-cultural readability." Perspectives. Studies in Translation Theory and Practice, vol. 20, no. 2, 2012, pp. 231-247. doi.org/10.1080/ 0907676X.2012.659746.

Tan, Zaixi. "Censorship in Translation: The Dynamics of Non-, Partial and Full Translations in the Chinese Context." Meta, vol. 62, no. 1, 2017, pp.45-68. doi:10.7202/1040466ar. 
Teng, Wei. Bianjing zhi nan. Ladingmeizhou wenxue hanyi yu zhongguo dangdai wenxue

(1949-1999). Peking University Press, 2011.

Vargas Llosa, Mario. Conversación en La Catedral. Alfaguara, 2004.

---. Jiuba changtan. Trans. Jiameng Sun. People’s Literature Publishing House, 1993.

--.. Jiuba changtan. Trans. Jiameng Sun. People’s Literature Publishing House/99 Readers, 2011.

Vázquez-Ayora, Gerardo. "Estudio estilístico de El otoño del patriarca, de Gabriel

García Márquez.” Dispositio, vol. 2, no. 5/6, 1977, pp. 160-181. www.jstor.org/stable/ 41491118, last visit 12/01/19.

---. “La traducción de la nueva novela latinoamericana al inglés." Babel, vol. 34, no. 1, 1978, pp. 4-18.

Venuti, Lawrence. "World literature and translation studies." The Routledge Companion to World Literature. Eds. Theo D'haen, David Damrosch, and Djelal Kadir. Routledge, 2012, pp. 180-193.

Zeng, Lijun. Ma'erkesi zai Zhongguo. China Social Sciences Press, 2012. 